\title{
Banks' Payments-Driven Revenues
}

\author{
Lawrence J. Radecki \\ Research and Markets Analysis Group \\ Federal Reserve Bank of New York \\ 33 Liberty Street \\ New York, New York 10045 \\ Telephone: (212) 720-5656 Fax: (212) 720-8363 \\ E-mail: Lawrence.Radecki@ny.frb.org
}

\begin{abstract}
The amount of fee income earned by the banking sector suggests that the significance of payment services has been understated or overlooked. This paper attempts to develop a clearer picture of the importance of payment services to the industry by delineating the payments area broadly and by analyzing data disclosed in bank holding company annual reports on sources of noninterest income.

We find that payment services bring in from one-third to two-fifths of the combined operating revenue of the twenty-five largest bank holding companies. This contribution to revenue is considerably larger than commonly appreciated and indicates that the production and distribution of payment services is one of the core activities of commercial banks. The greater-than-expected importance of payment services has several implications for the identification and measurement of the banking sector's output and for theories of the fundamental nature of commercial banking.

JEL codes: G20, G21

Keywords: Banks, Deposits, Payments

The views expressed in this paper are those of the author and do not necessarily reflect the position of the Federal Reserve Bank of New York, the Federal Reserve System, or their staffs. The author thanks the members of the Banking Studies and Payments Studies Functions at the Federal Reserve Bank of New York and the System Research Committee on Bank Structure and Regulation for their comments.
\end{abstract}




\section{Introduction}

Banks' lending activities draw the attention of supervisors, lawmakers, researchers, and the press, but a very substantial and growing portion of the industry's total revenue is received in the form of fee income. The amount of fee, or noninterest, income earned by the banking sector suggests that the significance of payment services has been understated or overlooked. A lack of good information on the payments area may partly explain a failure to gauge the size of this business line correctly. In reports to supervisory agencies, banking organizations provide data bearing primarily on their safety and soundness. By the design of the reports, banks transmit information on profitability, capital, and the size and condition of the loan portfolio. Limited information can be extracted from regulatory reports on individual business lines; in fact, they imply that banks receive just seven percent of their net revenue from payment services.

A narrow delineation of payment, or transaction, services may also contribute to a poor appreciation of this banking function. While checking accounts are universally recognized as a payment service, credit cards, corporate trust accounts, and securities processing should also be treated as parts of a bank's payments business. The common but limited definition of the payments area reflects the focus of banking research. Economists offer two explanations for the prominence of commercial banks in the financial sector. First, by developing their skills at screening applicants, monitoring borrowers, and obtaining repayment, commercial banks became the dominant lender to relatively smallsized borrowers. Second, because investors demand protection against the risk that they may need liquidity earlier than anticipated, bank deposits are a special and highly desired type of financial instrument. While insightful, neither rationale explains why commercial banks provide payment services on a large scale, or why they perform payment services together with deposit-taking and information-intensive lending. ${ }^{1}$

The purpose of this paper is to develop a clearer picture of the importance of payment services to the banking industry. This purpose is served by taking a broad view

${ }^{1}$ Recently, however, researchers have given greater attention to payment system issues. For surveys of the issues, see Berger, Hancock, and Marquardt (1996) and Hancock and Humphrey (1998). 
of the payments business and applying information provided by large bank holding companies (BHCs) in their annual reports. BHCs have made concerted efforts to improve their financial disclosures and they now furnish detailed material, far beyond what is filed in regular reports to supervisors, on sources of noninterest income and the amounts earned. This information is used to estimate the size of the payments area.

In the first section of the paper, we clarify our delineation of the payments area. Then in the second section we review aggregate data on noninterest revenue. We also examine the categories of noninterest income used in supervisory reporting to better understand what is captured in each. In the third section, we classify and measure sources of payments-driven revenue. Information appearing in the annual reports of BHCs is employed to estimate the amounts that payment services contribute to the industry's revenue stream. Our estimates show that aggregate payments-driven revenue is considerably larger than commonly appreciated and that the production and distribution of payment services are one of the core activities of commercial banking. In the last section we draw some implications from the greater-than-expected importance of payment services for the identification and measurement of the banking sector's output and theories of the fundamental nature of commercial banking.

\section{Delineation of payment services}

Everyone is familiar with the fact that banks provide payment services by safekeeping, administering, reporting on, and transferring money held in a deposit account. Less fully appreciated are the various payment services performed outside a deposit account relationship. These payment services fall into two basic types: securities handling and credit cards.

Banks furnish a set of securities handling services to their corporate and institutional customers, including pension funds, mutual funds, and endowments. These services involve safekeeping, administering, reporting on, and transferring ownership and settling trades of financial and real assets held in a trust department account. Additional services are performed on behalf of an issuer of debt or equity securities. Because of the essential similarities to deposit account services, we consider these trust department 
services as part of the payments business. Likewise, because of the essential similarities to payments initiated electronically from a deposit account, credit card transactions must be counted among the payment services that banks perform for retail customers. In effect, we are delineating payment services to encompass transferring money held in a deposit account, transferring money and assets held in a custodial account, and transferring money in accord with the terms of a credit agreement.

By developing a broad definition of payment services, we are making a sharper distinction between payment and liquidity services. A bank's liquidity services are viewed as the production of liabilities that have certainty of value, are readily redeemable, and can be converted into cash with small transactions costs. In this context, accepting time deposits with maturities as short as seven days while holding nonmarketable assets constitutes the production of liquidity services. At the same time, transaction services involve more activities than just the actual transfer of currency or federal funds to execute a Fedwire instruction, clear and settle a personal check, or meet a cash withdrawal at the teller window. In the future, the definition of transaction services will probably need to be expanded to comprise new systems that are currently under development or going through market tests. These new systems include multi-purpose stored-value cards and electronic forms of currency and checks for use over the Internet.

\section{Data sources}

Our starting point for assessing the importance of the payments business is information on noninterest income conveyed through regulatory reporting. The supervisory agencies collect data from BHCs through the $\mathrm{Y} 9 \mathrm{C}$ report, which is filed quarterly. These data show that the twenty-five largest BHCs earned a combined total of $\$ 62.4$ billion of noninterest income during 1996. (See the appendix for a list of the top twenty-five bank holding companies. ${ }^{2}$ )

Besides the total amount of noninterest income earned, a BHC records its

${ }^{2}$ Total assets at year-end 1996 is the criterion used to determine the twenty-five largest BHCs. Together the top twenty-five BHCs control almost two-thirds of total assets held by all BHCs and a little more than half of all bank and thrift deposits. 
composition by following a schedule of six categories: ${ }^{3}$

(1) service charges on deposit accounts in domestic offices,

(2) income from fiduciary (trust department) activities,

(3) trading revenue,

(4) net gains from foreign currency transactions conducted outside the trading account,

(5) other fee income, and

(6) all other noninterest income. ${ }^{4}$

For the twenty-five largest BHCs, table 1 shows the breakdown of noninterest income among these six components. Out of total noninterest income, the group of BHCs collected only $\$ 9.5$ billion from fees on deposit accounts in domestic offices. At first glance, it appears that the largest BHCs derive just 15.3 percent of noninterest income -and a mere 6.8 percent of operating revenue -- from payment services.

\section{Additional revenue from payment services}

The amount recorded as "deposit account fees" understates the revenue derived from payment services. According to the instructions to the filers of the $\mathrm{Y} 9 \mathrm{C}$ report, this category captures only those maintenance and activity fees that a bank collects directly from an owner of a deposit account at the same bank. But a bank can receive remuneration for payment services in three other ways and the associated revenues appear in other categories of income.

(1) Some fees triggered by deposit account activity are not reported in the category "deposit account fees."

${ }^{3} A$ seventh category, net realized gains on transactions involving held-tomaturity securities and available-for-sale securities, could be added. The gains made on sales of securities held outside the trading account can be thought of as an additional source of noninterest income. In fact, several BHCs include these securities gains in the figure for noninterest income they show in their annual reports.

${ }^{4}$ The Y9C report provides additional information through a supplementary schedule on which a BHC identifies and records figures for its largest sources of "all other noninterest income." 
While banks are correctly following the instructions for filling out the schedule for noninterest income, some activity fees wind up in the "other fee" category. "Misclassifications" occur because it is not the account holder who actually pays the activity fee, or it is not the bank providing the customer's deposit account that collects the activity fee.

(2) Some payment services are performed outside a deposit account relationship.

Some payment services are linked to a credit card account or a trust account instead of a deposit account, or in some cases, the payment service is separate from any account held at the bank. Thus banks do not report these revenues as "deposit account fees."

(3) Compensation for payment services takes the form of net interest income instead of noninterest income.

Banks receive a portion of their payment-related revenue as foregone interest on deposits or extra interest on loans, not in the form of a fee, commission, or other charge to the customer. This revenue would never appear on a schedule reporting noninterest income.

In sum, the figures collected quarterly for revenue earned through "fees on deposit accounts" are potentially misleading. On the surface, the schedule for noninterest income developed by supervisory agencies implies that this category represents the bulk of payments-driven revenue. But the $\mathrm{Y} 9 \mathrm{C}$ report delineates this category too narrowly to capture all noninterest income earned from payment services, and by definition it does not capture remuneration in the form of interest income.

\section{Bank holding company annual reports}

To measure the amount of payments-driven revenue earned by the largest BHCs, we rely on information disclosed in their annual reports. During the past several years, BHCs have taken significant steps to improve their financial disclosures. ${ }^{5}$ Their efforts have been made in concert with initiatives by the Securities and Exchange Commission, the Financial Accounting Standards Board, the Federal Reserve System, and other

\footnotetext{
${ }^{5}$ See Bank for International Settlements, 1994, and Edwards and Eller, 1996.
} 
entities, both public and private, to promote advances in accounting, reporting, and disclosure practices. Consequently, BHCs are providing more meaningful information on sources of noninterest revenue as well as off-balance-sheet activities, risk measurement and management methods, and results by line of business.

Particularly valuable to this study is detailed information on the business activities that bring in noninterest income and the amounts earned. For example, the BankAmerica Corporation shows figures on twenty categories of noninterest income in its annual report and thereby names a source for 86 percent of its total noninterest income of $\$ 5.4$ billion (table 2). Similarly, the Chase Manhattan Corporation shows figures on twenty-one categories and names a source for 88 percent of its $\$ 7.5$ billion of noninterest income (table 3). Both firms supplement quantitative disclosures with definitions and other qualitative information. The combination of data and supporting material makes it possible to estimate the amounts of payments-related revenue included in the categories "fiduciary fees," "other fee income," and "all other noninterest income."

In preparing a disclosure, each $\mathrm{BHC}$ chooses categories that correspond to its main sources of noninterest income. In addition, each BHC exercises its own judgment to determine the types of information and level of detail that would help shareholders, analysts, and others interested in understanding the performance of the company and its strategy. Because each BHC has a different mix of business lines and makes an independent judgment regarding what is genuinely useful, the formats of the disclosures are not uniform across BHCs. Consequently, disclosures of noninterest income are not strictly comparable across the industry, which imparts some imprecision to our estimates.

Furthermore, because each $\mathrm{BHC}$ is free to delineate its own set of categories, we encounter an additional complication. The categories of noninterest income appearing in an annual report do not necessarily bear a direct correspondence to categories defined by the Y9C report. In several cases, a category used by a BHC spans categories appearing in the Y9C report. Nevertheless, we believe that sufficient information can be extracted from annual reports to serve the purpose of this study.

${ }^{6}$ Some additional information on payments-related revenue can be extracted from line of business results disclosed in annual reports. 


\section{Estimating the volume of payments-driven revenue}

In this section, sources of payments-driven revenue are examined in the order they appeared earlier. First, we estimate "missed" deposit account activity fees and fees for payment services performed outside of a deposit account relationship. Then we measure interest income earned as compensation for payment services. For some types of payment services, the amount of revenue received is determined directly from the annual reports by adding up figures shown for a specific category of noninterest income. For other types, the amount earned is estimated by taking information on a subset of the twenty-five BHCs and extrapolating a combined total for the group.

Deposit account fees placed in the "other fee" category

The figure reported for "deposit account fees" does not capture all the revenue that a bank receives in the form of account maintenance and activity fees. In addition to those fees that a bank collects directly from its own deposit account customers, a bank charges fees for transactions initiated by customers of other banks or from the receivers of payments. Examples of these sources of fee income include:

- Interchange and merchant discount fees generated by use of an offline debit card. A card-issuing bank collects an interchange fee from a merchant, not from its customer who initiates the transaction. In addition, the bank handling or "acquiring" a debit card transaction on behalf of a merchant collects a discount fee from the merchant.

- Automatic teller machine (ATM) interchange fees and point-of-sale (POS) interchange and acquirer fees. When a bank's ATM is used by a deposit account customer of another bank, the owner collects an interchange fee from the card-issuing bank. Similarly, when a bank's POS device is used by a deposit account customer of another bank, the owner collects both an interchange fee and a merchant's fee for handling the transaction. ${ }^{7}$

${ }^{7} \mathrm{~A}$ card-issuing bank may assess fees on its own deposit account holders for use of an ATM or debit card, but this revenue would be recorded in "fees on deposit 
- $\quad$ ATM surcharge fees. These are fees imposed on users of a bank's ATM who are deposit account holders at another bank. ${ }^{8}$

Although all large banks with retail operations collect revenue from ATM and POS transactions, information on this type of noninterest income is relatively sparse in annual reports. Only six of the twenty-three banks with substantial retail operations identify a specific amount of revenue brought in by debit-ATM card transactions or electronic banking. Although several others cite a rise in electronic banking fees to explain an increase in noninterest income from the previous year, they simply record the revenue in the residual subcategory "other fee income." Among the BHCs that do disclose a specific figure, these fees are on average equal to 28 percent of deposit account fees. To approximate what the twenty-three BHCs earned in aggregate from electronic banking, we assume that the other seventeen BHCs earn proportional amounts of revenue from fees for electronic banking services. Therefore, we estimate that these fees came to $\$ 2.6$ billion during 1996, a healthy supplement to the $\$ 9.5$ billion of deposit account fees.

Banks may not be forthcoming about this source of revenue because they do not want to draw attention to the amount they charge customers for electronic banking. The industry has been criticized for setting what are said to be excessively high fees for basic banking services and for electronic access. The public finds ATM surcharges to be especially irksome because the installation of ATMs is supposed to cut operating expenses and allow banks to lower, not raise, deposit account fees.

\section{Credit card fees}

As argued earlier, transactions executed through credit cards must be included among the payment services performed for retail customers. But the dual nature of a bank-issued general-purpose credit card, combining a source of credit with a means of payment, makes it difficult to isolate the revenue earned specifically for transaction

accounts" since a card-issuer collects directly from its customers.

${ }^{8} \mathrm{~A}$ bank's ATM surcharge fee usually applies only to customers of other banks, but sometimes it applies to a bank's own customers for use of certain off-site ATMs. 
services. Nevertheless, we feel we can separate the revenues covering the cost of payment services from the revenues covering the cost of credit.

A credit card essentially combines a charge card, whose balance must be paid in full monthly, and a revolving line of credit. ${ }^{9}$ Keeping in mind the distinction between these two types of payment cards, it appears that nearly all of the noninterest revenue generated by credit cards can be attributed to their use as a payment device rather than tapping a credit line. In other words, noninterest revenue brought in by credit cards would still flow to banks if the cards were transformed into charge cards and a customer made separate arrangements to secure a revolving line of credit. We estimate credit card revenues under this assumption.

Noninterest revenue derived from the use of credit cards is recorded in "other fees" and takes several forms:

- Fees for handling transactions on behalf of merchants. A bank charges a merchant for obtaining payment from a card-issuer and transferring funds into a deposit account designated by the merchant.

- Fees for handling transactions on behalf of cardholders. A card-issuing bank receives an interchange fee for settling a transaction with a merchant, extending credit to a cardholder during the grace period, and supporting a cardholder's account. $^{10}$

- Fees for late payments, exceeding the account's limit, and annual account maintenance. A card-issuing bank collects these fees from cardholders.

A card-issuing bank may also earn fee income for servicing securitized credit card receivables, but analysis of these revenues is deferred to the section dealing with interest earned as compensation for payment services.

Among the twenty-five largest BHCs, twenty-two show an amount for credit card

\footnotetext{
${ }^{9}$ It should be noted that the normal use of a charge card requires extensions of credit by the card-issuer. Because a merchant receives payment from a card-issuing bank well before a cardholder remits money to the card-issuer, extensions of credit are a matter of course.

${ }^{10}$ Credit card associations also collect a fee on each transaction to pay for promotional activities, fraud prevention, and arranging interbank settlements.
} 
receivables outstanding. ${ }^{11}$ These loans, which appear on a bank's balance sheet, totaled $\$ 101.6$ billion for 1996. A larger amount, $\$ 156.1$ billion, is reported for the group's combined managed credit card receivables, which includes securitized receivables. Eighteen BHCs out of the twenty-two showing credit card loans disclose the amount of noninterest revenue that comes specifically from credit cards. In four cases, however, the figure includes an amount for servicing securitized receivables that cannot be broken out.

We will work with data on credit card fees provided by the fourteen BHCs that either do not securitize any of their receivables or exclude revenue earned by servicing their securitized receivables. These fourteen BHCs held $\$ 62.6$ billion of credit card receivables on their balance sheets and securitized an additional $\$ 25.8$ billion of receivables. From total managed receivables, they earned $\$ 3.1$ billion of fee income, equal to 3.46 percent of managed receivables. By applying this percentage to the total volume of managed credit card receivables held by all twenty-five BHCs, we estimate that the group earned a combined $\$ 5.4$ billion from credit card fees, which is more than half as large as the $\$ 9.5$ billion earned through fees on deposit accounts. Thus fees collected on credit card transactions supplement deposit account fees nicely. ${ }^{12}$

Fee income for securities handling and other processing services

${ }^{11}$ One $\mathrm{BHC}$ shows a figure for credit card loans on the $\mathrm{Y} 9 \mathrm{C}$ and not in its annual report, but the amount is trivial. The total of credit card loans shown in the Y9C report, however, is about 30 percent larger than the total obtained from the annual reports. One reason the $\mathrm{Y} 9 \mathrm{C}$ figures are larger is that data are reported as of the end of the year and are swollen during the holiday shopping season, whereas the annual report figures are usually an average for the year. Another reason is that the category used in the Y9C report is defined to include not only credit cards but also other revolving consumer credit plans; the figures in the annual reports may refer strictly to credit cards. Finally, some of the largest credit card issuers bought portfolios from other issuers over the course of the year.

${ }^{12}$ This estimate could be on the low side because some credit card fees are not identified and are left out of the calculations. For example, one bank states that late fees and charges for exceeding one's account limit are not recorded in "credit card revenue" but in an unspecified component of "other fee" category. On the other hand, estimated credit card fees may be too high because figures for merchant fees and interchange fees could include revenue derived from debit card usage. 
The securities handling services performed by a bank's trust department can be classified as: ${ }^{13}$

(1) Master trust and custody: acting as custodian or safekeeper, recordkeeper, and administrator (involving disbursements, tax payments, and accounting services) of securities and other assets, and providing trade execution, settlement, cash management, foreign exchange execution, and information services (including investment performance measurement and customized reporting) for private pension plans, public pension plans, and institutional trust funds.

(2) Global custody: acting as custodian for foreign assets, which requires multicurrency reporting, accounting, and cash management.

(3) Corporate trust: acting as trustee, fiscal agent, paying agent, registrar, and defeasance escrow agent for the issuer of bonds, commercial paper, or other debt instruments.

(4) Stock transfer: acting as transfer agent and dividend paying agent for an equity issuer. Mutual fund services are a type of stock transfer service.

In addition to securities processing, BHCs provide wholesale or institutional customers, including depository institutions, other processing services through subsidiaries. These include the processing of checks, airline coupons, remittances with their accompanying documents, and ATM, POS, and credit card transactions.

Nineteen BHCs in the group state an amount of noninterest income earned by handling securities and performing related services. (The others may earn some revenue this way but do not disclose an amount.) Eight BHCs specialize in wholesale payment services, produce them on a large scale, and earn more from these services than they do from deposit account fees. Collectively for the nineteen BHCs, this business line brings in $\$ 6.5$ billion of noninterest revenue, almost three-quarters as large as deposit account fees.

${ }^{13}$ Other services offered through a trust department would include portfolio management, securities lending, and financial advice. 
Interest income earned in return for payment services

An estimate of payments-driven revenue that only takes noninterest income into account understates the total amount of revenue brought in by payment services. This is because a component of net interest income is actually compensation for a payment service, not an extension of credit. Depositors compensate banks by foregoing interest on their balances in addition to paying explicit account maintenance and activity fees. ${ }^{14}$ Customers earn no interest on demand deposits and earn below market rates on deposits in NOW, savings, and money market accounts. Interest revenue substitutes for higher explicit fees. In an analogous way, credit card customers compensate banks for transactional services by paying interest on their balances that is above the cost of just the loan. Again interest revenue substitutes for explicit maintenance and activity fees. Therefore, to construct a comprehensive figure for the contribution of payment services to operating revenue, the amount of net interest revenue generated by payment services must be broken out of total net interest income. ${ }^{15}$

To estimate foregone interest on deposit accounts, we first assume that deposits in all accounts that have payment capabilities, principally checkwriting privileges and immediate remote withdrawal or transfer, implicitly earn the federal funds rate. We also assume that the sum of foregone interest and explicit fees equals all maintenance and activity costs incurred by a bank. Under these assumptions, the twenty-five BHCs earned $\$ 15.5$ billion of foregone interest on $\$ 295.5$ billion of demand deposits and $\$ 13.3$ billion of foregone interest on deposits of $\$ 502.6$ billion in NOW, money market, and conventional

${ }^{14}$ Corestates acknowledges implicit interest as compensation for payment services in its 1996 annual report: "Service charges on deposit accounts, paid in fees, decreased $\$ 0.7$ million, or $0.3 \%$, [to $\$ 243.7$ million] in 1996, compared to an increase of $\$ 4.6$ million, or $1.9 \%$, in 1995 . After adding the value of service charges paid through the maintenance of deposit balances by commercial and correspondent customers, which is included in net interest income, total service charge compensation for 1996 was $\$ 470.4$ million, up $\$ 19.6$ million, or $4.4 \%$, from 1995 reflecting growth in transaction volume." (page 39)

${ }^{15}$ Studies of the demand for money also recognize the phenomenon of implicit interest on deposit accounts. They estimate the amount of implicit interest earned on demand deposits for the purpose of calculating the opportunity cost of holding money. 
savings accounts. By comparison, the $\$ 28.8$ billion of interest foregone is almost three times as large as the fees collected on deposit accounts. ${ }^{16}$

Foregone interest from deposit accounts may seem extraordinarily large, but it must cover the sizable expenses of running a bank's branch network, whose primary purpose is to handle the transaction needs of household and small business customers. In analyzing banks' retail operations, industry sources estimate that a large BHC bears annual noninterest expenses at a typical branch on the order of $\$ 1$ million to $1 \frac{1}{2}$ million: half incurred at the branch itself and half at headquarters and centralized operating facilities. If a branch holds $\$ 50$ million of retail deposits, the implied noninterest expense ratio is 2 to 3 percent of deposits. Some expenses are recovered by collecting fees on deposit accounts and for ancillary services offered at the branch office. The remainder must be recovered through foregone interest. Since no explicit interest is paid on demand deposits, they earn a high rate of foregone interest (equal to the federal funds rate, which averaged more than 5.00 percent during 1996), but they also have high maintenance and activity expenses. Although they have lower maintenance and activity costs, savings, money market, and NOW accounts bring in less foregone interest per dollar of deposit because some interest is paid on balances held in these accounts.

\section{Credit cards}

As described above, foregone interest earned on deposits is calculated by applying a market-based interest rate uniformly to all core deposits. A parallel calculation to determine the extra interest revenue collected from credit card holders cannot be carried out for two reasons. First, no readily observable consumer loan rate is available to serve as a benchmark. Second, a benchmark rate would vary across households because some are much better credit risks than others.

A substitute method is used to estimate the amount of extra interest paid on credit card balances. It relies on information on revenue earned for servicing securitized credit

\footnotetext{
${ }^{16}$ Berger and Humphrey (1992) report comparable figures for all commercial banks. They estimate forgone interest on demand, savings, time, and other deposits to be $\$ 41.9$ billion in 1988 , compared with $\$ 9.4$ billion of fees on deposit accounts.
} 
card receivables. In a securitization, most of the interest paid by cardholders passes to the owner of the security, who funds the loans and bears the credit risk. A smaller portion of the interest paid by cardholders is retained by the card-issuing bank. The card-issuer's revenue from securitized receivables is used to estimate the extra interest paid for payment services rendered through the card. In other words, the retained portion of interest paid is, in theory, the amount cardholders would be assessed in explicit activity fees and maintenance charges on their accounts if interest were not used instead. ${ }^{17}$

Ten of the twenty-two BHCs offering credit card accounts securitized part of their receivables. Six of these ten disclose detailed information on the volumes of their securitization programs and the impact on net interest income, provisions for loan losses, and noninterest revenue. ${ }^{18}$ On average, securitization reduces net interest income by an amount equal to 8.33 percent of the dollar volume securitized. More than half of this reduction, 5.50 percent of the dollar volume securitized, reflects provisioning for loan losses. The card-issuer pockets the remainder (plus a small residual), 3.05 percent, and records it as noninterest income. It serves as our estimate of extra interest paid on all credit card receivables. Applying the estimate of 3.05 percent to the entire $\$ 156.1$ billion of managed credit card receivables implies that the group of twenty-five BHCs collected $\$ 4.8$ billion of extra interest from cardholders as compensation for payment services.

Because extra interest paid on credit card balances is determined from a residual, it is probable that our estimate captures more than just the interest paid to cover the costs of performing payment services. The residual may pick up excess profits from credit card operations, an implicit charge for the unused portion of a cardholder's credit line, the cost of maintaining a loan account, and compensation for any residual credit risk retained by a card issuer. For this reason, it is proper to consider the estimate of $\$ 4.8$ billion as the

${ }^{17}$ Issuers of charge cards cannot cover transactions costs by collecting interest as issuers of general-purpose credit cards can. This would seem to explain why charge card issuers set higher annual fees and higher merchant discount fees than credit card issuers.

${ }^{18}$ These six BHCs hold nearly half of the top twenty-five BHCs' combined credit card receivables. Individually, they securitized between 5 and 45 percent of their credit card receivables. On average, they securitized 35 percent. 
upper bound of extra interest paid by cardholders.

\section{Summing up}

By adding up all the pieces of revenue identified above, we find that payment services contribute as much as $\$ 57.6$ billion, or 41.1 percent, to the combined operating revenue of $\$ 140.2$ billion earned by the twenty-five largest BHCs (table 4). Payment services bring in $\$ 24.0$ billion in the form of fee income, which is a little less than 40 percent of the group's combined noninterest income. A larger amount, between $\$ 28.8$ billion and $\$ 33.6$ billion, is received as interest revenue, accounting for 37.0 percent to 43.2 percent of the group's combined net-net interest income. Among categories of payment services, deposit accounts yield the most revenue, $\$ 40.9$ billion, although only $\$ 12.1$ billion comes from service charges. Credit cards bring in between $\$ 5.4$ billion and $\$ 10.2$ billion and securities handling and other processing services another $\$ 6.5$ billion. $^{19}$

The very substantial amount of revenue derived from payment services indicates that their production and distribution constitute one of the main business activities of commercial banks. The size of payments-related income also implies that lending contributes less revenue than is commonly believed. The income from payment services together with fee income from other non-credit services -- including insurance, securities underwriting, brokerage, advisory services, equity investments, and portfolio management -- may account for half or more of combined operating revenues. Income earned by extending credit probably contributes the single largest share of operating revenue, but

${ }^{19}$ Industry consultants have also prepared estimates of payment system revenues, but they have a wider scope than this study. Bowers and Devine (1995) placed total payment system revenues at $\$ 84$ billion in 1993. This figure, however, appears to include all interest paid on credit card balances and mixes credit services with payment services. The Bank Administration Institute and Payment Systems, Inc., have completed a study, "Profiting from Change in the U.S. Payments System," described by Chambliss and Taylor (1997), which estimates that the banking industry's fee income from payment services was $\$ 22$ billion in 1996 and interest income from payment services was $\$ 78$ billion. Their estimate of total payments-driven fee income looks low compared to ours, which is based on just the twenty-five largest BHCs. Their interest income figure appears to include all interest paid on credit card balances, and likewise mixes credit services with payment services. 
it is clearly an oversimplification to characterize banking organizations as financial institutions that take in deposits in order to make loans.

The significance of payments-driven revenue helps explain the intense intraindustry and inter-industry competition that has broken out in the payments area. Large banks are working hard to promote electronic payments media despite projections of slow consumer acceptance and uncertain cost effectiveness. The objective appears to be to eventually take business away from competitors as well as create new demands for transaction services. Furthermore, efforts to develop new payment systems are not only an offensive maneuver, but also a defensive stratagem. The payments business has attracted the attention of firms outside the industry, in particular, "technology" firms committed to developing new payment systems. ${ }^{20}$ Banks are fighting to hold on to their position in the payments area and to keep nonfinancial firms from encroaching on this essential business line.

\section{Implications}

Surveys of research on financial intermediation highlight many interesting but unresolved issues. This paper's findings on the amount of revenue derived from payment services point to three topics that deserve a fresh look: (1) the specification and measurement of bank output, (2) the contribution of off-balance-sheet activities to bank output and operating revenue, and (3) characteristics that distinguish commercial banks from other financial intermediaries.

\section{Measurement of banking output}

It is often said that commercial banking is a service industry for which it is especially troublesome to identify and measure output. One approach researchers take to this

\footnotetext{
${ }^{20}$ Given the contribution that payments-related income makes to operating revenue, $\mathrm{BHCs}$ are taking substantial business risks whenever they make important decisions regarding the payments business. BHCs must decide which services to offer and on what scale, what hardware and software investments to make, whether to produce in-house or outsource some aspects of these services, and which partners to take on in joint ventures. The business risks in the payments area have different dimensions from those in lending or trading, but they are present nonetheless.
} 
problem is to stress a bank's role as an intermediary between borrowers and savers and measure output by the dollar volume of loans or assets recorded on the balance sheet. Deposits are treated as an input. An intermediation approach is appealing for its simplicity but is not congruent with the main findings of this paper. The vital contribution made by payment services signifies that this approach to banking is too narrow, at least for the group of institutions studied here.

Some researchers have taken a value-added approach instead, which in principle can treat both asset and liability categories as outputs. This flexibility leads to a better theoretical model of a banking firm because payment services can be recognized as outputs. A value-added approach, however, may still be inadequate when put in practice. Researchers generally conduct econometric studies by forming a short list of outputs; for example, demand deposits, savings and small time deposits, real estate loans, commercial and industrial loans, and consumer installment loans. Implicit in this specification is the restriction that payment services are supplied in proportion to the volume of core deposits. This constraint makes the value-added model too limiting, given the heterogeneity in both the amount and mix of payment services produced by the top twenty-five BHCs.

The variation in payments-driven revenue across individual banks is highlighted in table 5. The top twenty-five banking organizations are ranked in the table, not by size, but by share of operating revenue contributed by the payments business. The bank that is most dependent on the payment business earns three-quarters of its operating revenue from this business line. The magnitude of payments-driven revenue at this bank reflects its specialization in both credit cards and securities processing. Several other banks among the top twenty-five also earn more than ten percent of their operating revenue from either credit cards or securities processing. The outputs generating these revenues are not highly correlated with the dollar volume of any asset or liability reported on the balance sheet. Nor will these outputs be correlated with figures for categories of off-balance-sheet instruments. Consequently, a value-added approach remains flawed even if more balance sheet items or instrument categories are specified.

Against this background, studies of productivity, economies of scale and scope, and the effects of consolidation and technological change look to be less reliable than 
previously thought. Similarly, studies comparing the efficiency of banking organizations look questionable. Their findings of high and variable degrees of inefficiency across a sample of banks may actually reflect differences in the amount and mix of payment services they produce. In addition, studies assessing the effects of investment in new systems and equipment may not find efficiency gains if they occur predominantly in the payments area and payment services are not recognized as bank outputs.

\section{Importance of off-balance-sheet activities}

Reacting to the growing contribution that noninterest income makes to operating revenue, some researchers have sought to refine the measurement of bank output. They have developed two methods of recognizing off-balance-sheet activities. The first takes into account the credit exposure that off-balance-sheet instruments present to a bank. The potential credit exposure from unused credit lines and other lending commitments and the implicit credit exposure from interest rate swaps and other derivative contracts are added to loans recorded on the balance sheet. The resulting quantity is interpreted as an augmented measure of credit intermediation and bank output (Edwards and Mishkin, 1995). The second method treats off-balance-sheet instruments as a separate bank output. The quantity of output embodied in off-balance-sheet instruments is approximated by a volume of hypothetical on-balance-sheet loans -- the volume needed to yield net interest income equal to a bank's reported noninterest income. The volume of hypothetical on-balance-sheet assets is then considered to be a component of bank output along with volumes of loans and deposits (Clark and Siems, 1997).

Our review of noninterest income earned through payment services reveals that both approaches are flawed. The problem with the first approach is that off-balance-sheet instruments that present credit risk are not the main source of noninterest income. Many other bank products besides derivative contracts and loan substitutes bring in noninterest income and we have identified several of these as payment services. Consequently, important outputs are still unrecognized, although adding off-balance-sheet credit exposure to loan volumes may be a valid adjustment to make in pursuit of a comprehensive measure of bank lending. The problem with the second approach is that 
it assumes that all noninterest income is generated by off-balance-sheet instruments that present credit risk. Converting all noninterest income earned into a balance-sheetequivalent volume of loans overstates lending and understates the size of other business lines.

Derivative contracts and loan substitutes

Because a surprisingly large portion of noninterest income is payments-driven, the contributions made by loan commitments and derivatives trading may be less than generally assumed. To find the amount of revenue earned from these activities, we again turn to BHC annual reports. Three BHCs among the largest twenty-five disclose a comprehensive figure for fee income earned from off-balance-sheet forms of lending: BankAmerica, Chase Manhattan, and J.P. Morgan. BankAmerica states that during 1996 it earned $\$ 345$ million of noninterest income from fees collected for "off-balance-sheet lending activities," Chase Manhattan identifies \$330 million from "letters of credit and acceptances" and \$120 million from "loan commitment fees," and J.P. Morgan mentions $\$ 156$ million earned primarily from "commitments to extend credit, standby letters of credit and securities lending indemnifications." The amounts disclosed represent, respectively, 6 percent, 6 percent, and 3 percent of each company's total noninterest income. ${ }^{21}$ These small percentages indicate that off-balance-sheet credit instruments do not bring in sufficient fee revenue to be a major factor behind the rising long-term trend in noninterest income.

Measuring trading revenue is straightforward because figures are presented in regulatory reports and shareholders' annual reports. But BHCs do not typically separate revenue earned by trading derivatives from revenue earned by trading conventional securities. If we assume arbitrarily that half of total trading revenue is obtained from

\footnotetext{
${ }^{21}$ Three other BHCs disclose a figure that is not comprehensive but only covers fees earned from letters of credit and acceptances. Bank of Boston Corporation shows that it earned $\$ 68$ million from "letters of credit and acceptance fees" (5 percent of its total noninterest income); KeyCorp $\$ 16$ million from "letters of credit fees" (11/2 percent of its total noninterest income); and Wachovia Corporation \$25 million from "bankers acceptances and letter of credit fees" (3 percent of its total noninterest income).
} 
derivative contracts, the twenty-five BHCs earned almost $\$ 4$ billion from dealing in offbalance-sheet instruments. This represents 6 percent of total noninterest income earned by the group. In light of the shares of noninterest income brought in by trading and loan commitments, we conclude that the contribution that these off-balance-sheet activities make to operating revenue has been exaggerated.

\section{The essence of commercial banking}

The sizable contribution made by payment services to the revenue stream of large $\mathrm{BHCs}$ also leads us to reconsider the problem of delineating the essential features of commercial banks. What is called for is an integrated theory of commercial banking, one that explains why commercial banks provide payment services in large scale and that identifies the characteristics needed to succeed in payment services as well as taking deposits and intermediating credit. ${ }^{22}$ In an attempt to explain the coincidence of payment services and lending in a single financial intermediary, we offer the following solution: the know-how required to succeed in the payments business is the ability to control losses efficiently. Losses from payments activities can arise from fraud, operational glitches, systemic breakdowns, and failures of counterparties to perform as obligated on account of bankruptcy or other reasons. The skills necessary in the payments area encompass both preventing losses and recovering funds in the event of a loss. This means that a bank's personnel must be able to prevent fraud, write contracts that offer legal protection, assess credit risk, get back funds that should not have been sent out, and claim compensation for damages. These skills would seem to carry over to the lending business, where a bank must also know how to prevent losses and make recoveries. The common set of skills required by these two business lines may be the explanation for the fact that commercial banks provide both lending and payment services, which

${ }^{22}$ In the course of reviewing the development of the U.S. payment system, Goodfriend (1991) explored reasons why "payment services and information-intensive lending have been provided jointly by the same set of institutions, i.e., banks." 
distinguishes banks from other classes of financial intermediaries. ${ }^{23}$

\section{Conclusion}

This paper set out to gauge the importance of the payments business to the banking industry, measured in terms of the revenue that payment services generate. Our first step was to set the limits of the payments area broadly to include not only deposit accounts, but also securities processing and credit cards. We then turned to $\mathrm{BHC}$ annual reports to supplement information collected through regulatory reporting on the revenues earned from payment services.

By adding up all the pieces of fee income and interest income that is earned as compensation for transactional services, we find that the payments business generates between one-third and two-fifths of the combined operating revenue of the twenty-five largest BHCs. Payment services thus make a significant and surprisingly large contribution to the industry's revenue stream.

Looking forward, the payments franchise may produce an even greater proportion of banks' operating income. First, if current trends persist, trading of financial instruments will expand and banks will handle larger volumes of transactions and earn more fee income. Second, as higher proportions of household-to-business and business-tobusiness payments are converted to electronic formats, bank customers will make and receive payments faster and more conveniently. For improved payment services, banks should be able to raise their fees.

Based on the revenues they now yield, payment services constitute one of the integral activities of the banking industry and are on an equal footing with credit services. This means the production and distribution of payment services should be incorporated in both theoretical and empirical research on the banking sector. By excluding payment services in a model of a banking firm, a researcher may be overlooking one of its defining

${ }^{23}$ Fama (1985) conjectured that a bank's ability to view a firm's deposit account activity is what gives it an edge over nonbank financial intermediaries, as well as other banks, in lending to holders of a deposit account at the same bank. Nakamura (1993) assembled quantitative information that supports the view that at least small banks have an advantage owing to their handling of a loan applicant's deposit accounts. 
characteristics. 


\section{Appendix}

The twenty-five largest bank holding companies as of year-end 1996, measured by total assets:

The Chase Manhattan Corporation

Citicorp

BankAmerica Corporation

J.P. Morgan \& Company, Incorporated

Nationsbank Corporation

First Union Corporation

Bankers Trust New York Corporation

Wells Fargo \& Company

First Chicago NBD Corporation

Banc One Corporation

Fleet Financial Group, Incorporated

Norwest Corporation

PNC Bank Corporation

Keycorp

Bank of Boston Corporation

Bank of New York Company, Incorporated

Suntrust Banks, Incorporated

Republic New York Corporation

National City Corporation

Wachovia Corporation

Corestates Financial Corporation

Mellon Bank Corporation

Barnett Banks, Incorporated

Boatmen's Bancshares, Incorporated

First Bank System, Incorporated 


\section{Bibliography}

The 1996 Annual Reports of the twenty-five largest bank holding companies.

Bank for International Settlements: Euro-currency Standing Committee, "A Discussion Paper on Public Disclosure of Market and Credit Risks by Financial Intermediaries" (1994).

Berger, Allan N., Diana Hancock, and Jeffrey C. Marquardt, "A Framework for Analyzing Efficiency, Risks, Costs, and Innovations in the Payments System," Journal of Money, Credit, and Banking (November 1996, part 2), pages 696-732.

Berger, Allen N., and David B. Humphrey, "Measurement and Efficiency Issues in Commercial Banking," in Output Measurement in the Service Sectors (1992), edited by Zvi Griliches with the assistance of Ernst R. Berndt, Timothy F. Bresnahan, and Marilyn Manser, University of Chicago Press, pages 245-79.

Bowers, Tab, and Ted Devine, "The Next Upheaval in the U.S. Payments System," The McKinsey Quarterly, number 4 (1995), pages 74-84.

Chambliss, Neal, and David Taylor, "Prevailing in Payments," Bank Administration Institute Magazine (September-October 1997).

Clark, Jeffery A., and Thomas F. Siems, "Competitive Viability in Banking: Looking Beyond the Balance Sheet," Federal Reserve Bank of Dallas Working Paper (December 17, 1997).

Edwards, Franklin R., and Frederic S. Mishkin, "The Decline of Traditional Banking: Implications for Financial Stability and Regulatory Policy," Federal Reserve Bank of New York Economic Policy Review (July 1995), pages 27-45.

Edwards, Gerald A., Jr. and Gregory E. Eller, "Derivatives Disclosures by Major U.S. Banks, 1995," Federal Reserve Bulletin vol.82 (September 1996), pages 791-801.

Fama, Eugene, "What's Different About Banks?" Journal of Monetary Economics (1985), pages 29-39.

Goodfriend, Marvin, "Money, Credit, Banking, and Payments System Policy," Federal Reserve Bank of Richmond Economic Review (January/February 1991), pages 7-23.

Hancock, Diana, and David B. Humphrey, "Payment Transactions, Instruments, and Systems: A Survey," Journal of Banking and Finance (1998), pages 1573-1624.

Nakamura, Leonard I., "Commercial Bank Information: Implications for the Structure of Banking," in Michael Klausner and Lawrence J. White, eds., Structural Change in Banking, Homewood, IL: Business One/lrwin, 1993, pages 131-60. 
Table 1

Composition of operating revenue for the largest BHCs during 1996

\begin{tabular}{|c|c|c|c|}
\hline Category of income & Combined totals & $\begin{array}{c}\text { As a percent of } \\
\text { operating revenue }\end{array}$ & $\begin{array}{c}\text { As a percent of } \\
\text { assets }\end{array}$ \\
\hline (1) Total noninterest income & $\$ 62.4$ billion & 44.5 & 2.32 \\
\hline $\begin{array}{l}\text { Service charges on deposit } \\
\text { accounts (in domestic offices) }\end{array}$ & $\begin{array}{l}\$ 9.5 \text { billion, or } \\
15.3 \text { percent of total } \\
\text { noninterest income }\end{array}$ & 6.8 & 0.36 \\
\hline Income from fiduciary activities & $\$ 10.2$ billion & 7.3 & 0.38 \\
\hline Trading revenue & $\$ 7.9$ billion & 5.6 & 0.30 \\
\hline Other foreign currency gains & $\$-0.08$ billion & -0.06 & -0.003 \\
\hline Other fee income & $\$ 23.8$ billion & 17.0 & 0.89 \\
\hline All other noninterest income & $\$ 10.9$ billion & 7.8 & 0.41 \\
\hline (2) Gross interest earned & $\$ 181.2$ billion & 129.3 & 6.75 \\
\hline (3) Gross interest paid & $\$ 94.2$ billion & 67.2 & 3.51 \\
\hline (4) Net interest income: (2) - (3) & $\$ 87.0$ billion & 62.0 & 3.24 \\
\hline (5) Provisions for loan losses & $\$ 9.2$ billion & 6.5 & 0.34 \\
\hline $\begin{array}{l}\text { (6) Net-net interest income, or net } \\
\text { interest income less provisions for } \\
\text { loan losses: }(4)-(5)\end{array}$ & $\$ 77.8$ billion & 55.5 & 2.90 \\
\hline (7) Operating revenue: $(1)+(6)$ & $\$ 140.2$ billion & 100.0 & 5.22 \\
\hline Memo item: Total assets & $\$ 2686.0$ billion & ---- & ---- \\
\hline
\end{tabular}

Source: Y9C reports 


\section{Table 2}

Disclosure of sources of noninterest income: BankAmerica Corporation

\begin{tabular}{|c|c|}
\hline Categories of noninterest income & $\begin{array}{c}\text { Amount } \\
\text { earned } \\
\text { during } 1996 \\
\text { (in millions) }\end{array}$ \\
\hline 1 Deposit account fees -- retail & $\$ 1,057$ \\
\hline 2 Deposit account fees -- commercial & 342 \\
\hline 3 Credit card fees -- membership & 29 \\
\hline 4 Credit card fees -- other & 326 \\
\hline 5 Trust fees -- corporate and employee benefit & 18 \\
\hline 6 Trust fees -- personal and other & 211 \\
\hline 7 Other fees and commissions -- loan fees and charges & 336 \\
\hline 8 Other fees and commissions -- income from credit card securitizations & 28 \\
\hline 9 Other fees and commissions -- off-balance-sheet credit-related instrument fees & 345 \\
\hline 10 Other fees and commissions -- financial services fees & 216 \\
\hline 11 Other fees and commissions -- mutual fund and annuity commissions & 100 \\
\hline 12 Other fees and commissions -- other & 358 \\
\hline 13 Trading income -- interest rate exposures & 56 \\
\hline 14 Trading income -- foreign exchange exposures & 316 \\
\hline 15 Trading income -- debt instruments & 258 \\
\hline 16 Other noninterest income -- venture capital activities & 427 \\
\hline $\begin{array}{l}17 \text { Other noninterest income --net gain on sale of loans, premises and } \\
\text { equipment, and certain other assets }\end{array}$ & 197 \\
\hline 18 Other noninterest income -- net gain on sale of subsidiaries and operations & 180 \\
\hline 19 Other noninterest income -- gain on issuance of subsidiary's stock & 147 \\
\hline 20 Other noninterest income -- other & 404 \\
\hline Total noninterest income as defined in the $\mathrm{Y} 9 \mathrm{C}$ report & 5,351 \\
\hline Memo: Net gain on available-for-sale securities & 61 \\
\hline Total noninterest income as shown in the annual report adjusted & 5,412 \\
\hline
\end{tabular}

Source: 1996 Annual Report of the BankAmerica Corporation 


\section{Table 3}

Disclosure of sources of noninterest income: Chase Manhattan Corporation

\begin{tabular}{|c|c|}
\hline Categories of noninterest income & $\begin{array}{c}\text { Amount } \\
\text { earned } \\
\text { during } 1996 \\
\text { (in millions) }\end{array}$ \\
\hline 1 Corporate finance and syndication fees & $\$ 929$ \\
\hline 2 Trust, custody, and investment management fees & 909 \\
\hline 3 Mutual fund fees & 83 \\
\hline 4 Other trust fees & 184 \\
\hline 5 Credit card revenue -- from securitized receivables & 318 \\
\hline 6 Credit card revenue -- all other & 745 \\
\hline 7 Service charges on deposit accounts & 394 \\
\hline $\begin{array}{l}8 \text { Fees for other financial services -- commissions on letters of credit and } \\
\text { acceptances }\end{array}$ & 330 \\
\hline 9 Fees for other financial services -- fees in lieu of compensating balances & 295 \\
\hline 10 Fees for other financial services -- mortgage servicing fees & 204 \\
\hline 11 Fees for other financial services -- loan commitment fees & 120 \\
\hline 12 Fees for other financial services -- other fees & 580 \\
\hline 13 Trading income -- interest rate contracts & 535 \\
\hline 14 Trading income -- foreign exchange contracts & 444 \\
\hline 15 Trading income -- debt instruments and other & 994 \\
\hline 16 Other noninterest income -- gains from equity-related investments & 726 \\
\hline 17 Other noninterest income -- net losses on emerging market securities sales & -80 \\
\hline 18 Other noninterest income -- residential mortgage origination/sales activities & 63 \\
\hline 19 Other noninterest income -- loss on sale of a building in Japan & -60 \\
\hline 20 Other noninterest income -- from credit card securitizations & 23 \\
\hline 21 Other noninterest income -- all other revenue & 344 \\
\hline Total noninterest income as defined in the $\mathrm{Y} 9 \mathrm{C}$ report & 7,477 \\
\hline Memo: Securities gains & 135 \\
\hline Total noninterest income as shown in the annual report & 7,512 \\
\hline
\end{tabular}

Source: 1996 Annual Report of the Chase Manhattan Corporation 


\section{Table 4}

Summary of sources of operating income derived from payment services by the twenty-five largest bank holding companies

\begin{tabular}{|c|c|c|}
\hline Category & Revenue earned & Comment \\
\hline Fees on deposit accounts & $\$ 9.5$ billion & As recorded in the $\mathrm{Y} 9 \mathrm{C}$ reports. \\
\hline $\begin{array}{l}\text { Fees on deposit accounts } \\
\text { recorded in "other fee" }\end{array}$ & $\$ 2.6$ billion & Estimated from a sample of BHCs. \\
\hline Credit card fees & $\$ 5.4$ billion & $\begin{array}{l}\text { Estimated from a sample of BHCs; } \\
\text { excludes securitization revenue. }\end{array}$ \\
\hline $\begin{array}{l}\text { Securities handling and } \\
\text { processing }\end{array}$ & $\$ 6.5$ billion & $\begin{array}{l}\text { Sum of amounts disclosed in annual } \\
\text { reports. }\end{array}$ \\
\hline $\begin{array}{l}\text { Interest foregone by } \\
\text { deposit account holders }\end{array}$ & $\$ 28.8$ billion & $\begin{array}{l}\text { Estimated; } \$ 15.5 \text { billion from demand } \\
\text { deposits, and } \$ 13.3 \text { billion from NOW, } \\
\text { savings, and money market accounts. }\end{array}$ \\
\hline $\begin{array}{l}\text { Extra interest paid by credit } \\
\text { card holders }\end{array}$ & As much as $\$ 4.8$ billion & Estimated from a sample of BHCs. \\
\hline Total & $\begin{array}{l}\text { Between } \$ 52.8 \text { billion } \\
\text { and } \$ 57.6 \text { billion }\end{array}$ & $\begin{array}{l}\text { Between } 37.7 \text { and } 41.1 \text { percent of } \\
\text { operating revenue. }\end{array}$ \\
\hline \multicolumn{3}{|l|}{ Memo items: } \\
\hline \multicolumn{3}{|l|}{$\begin{array}{l}\text { Amount of revenue earned } \\
\text { in the form of: }\end{array}$} \\
\hline Noninterest income & $\$ 24.0$ billion & 38.5 percent of noninterest income. \\
\hline Net interest income & $\begin{array}{l}\text { Between } \$ 28.8 \text { billion } \\
\text { and } \$ 33.6 \text { billion }\end{array}$ & $\begin{array}{l}\text { Between } 37.0 \text { percent and } 43.2 \\
\text { percent of net-net interest income. }\end{array}$ \\
\hline \multicolumn{3}{|l|}{$\begin{array}{l}\text { Amount of revenue earned } \\
\text { from: }\end{array}$} \\
\hline Deposit accounts & $\$ 40.9$ billion & \\
\hline Securities handling & $\$ 6.5$ billion & \\
\hline Credit cards & $\begin{array}{l}\text { Between } \$ 5.4 \text { billion } \\
\text { and } \$ 10.2 \text { billion }\end{array}$ & \\
\hline
\end{tabular}


Table 5

Sources of payments-driven revenue across bank holding companies

\begin{tabular}{|c|c|c|c|c|c|}
\hline $\begin{array}{l}\text { Top } 25 \text { BHCs } \\
\text { ranked by } \\
\text { share of } \\
\text { payments- } \\
\text { driven } \\
\text { revenues }\end{array}$ & $\begin{array}{l}\text { Payments- } \\
\text { driven } \\
\text { revenue as a } \\
\text { percent of } \\
\text { operating } \\
\text { revenues }\end{array}$ & $\begin{array}{c}\text { Deposit } \\
\text { account } \\
\text { revenue as a } \\
\text { percent of } \\
\text { operating } \\
\text { revenue }\end{array}$ & $\begin{array}{c}\text { Credit card } \\
\text { revenue as a } \\
\text { percent of } \\
\text { operating } \\
\text { revenue }\end{array}$ & $\begin{array}{l}\text { Securities } \\
\text { processing } \\
\text { revenue as a } \\
\text { percent of } \\
\text { operating } \\
\text { revenue }\end{array}$ & $\begin{array}{l}\text { Operating } \\
\text { revenue } \\
\text { (in billions) }\end{array}$ \\
\hline $\begin{array}{l}1 \\
2 \\
3 \\
4 \\
5\end{array}$ & $\begin{array}{l}74.9 \\
58.3 \\
56.1 \\
54.9 \\
49.6\end{array}$ & $\begin{array}{l}39.1 \\
33.5 \\
40.2 \\
40.4 \\
44.7\end{array}$ & $\begin{array}{c}10.4 \\
22.0 \\
3.6 \\
14.5 \\
4.8\end{array}$ & $\begin{array}{c}25.4 \\
2.8 \\
12.3 \\
---- \\
0.1\end{array}$ & $\begin{array}{l}\$ 3.4 \\
5.2 \\
3.0 \\
2.2 \\
6.7\end{array}$ \\
\hline $\begin{array}{c}6 \\
7 \\
8 \\
9 \\
10\end{array}$ & $\begin{array}{l}49.0 \\
47.6 \\
47.4 \\
46.8 \\
46.1\end{array}$ & $\begin{array}{l}39.5 \\
34.7 \\
43.3 \\
40.2 \\
31.8\end{array}$ & $\begin{array}{l}3.7 \\
12.9 \\
4.1 \\
5.9 \\
6.7\end{array}$ & $\begin{array}{l}5.8 \\
--- \\
--- \\
0.7 \\
7.6\end{array}$ & $\begin{array}{l}2.8 \\
6.2 \\
2.5 \\
9.4 \\
2.6\end{array}$ \\
\hline $\begin{array}{l}11 \\
12 \\
13 \\
14 \\
15\end{array}$ & $\begin{array}{l}44.4 \\
44.0 \\
43.5 \\
43.4 \\
42.5\end{array}$ & $\begin{array}{l}21.0 \\
29.1 \\
41.0 \\
37.4 \\
37.9\end{array}$ & $\begin{array}{l}10.4 \\
4.4 \\
2.5 \\
6.0 \\
3.9\end{array}$ & $\begin{array}{l}13.0 \\
10.6 \\
---- \\
--- \\
0.7\end{array}$ & $\begin{array}{l}14.8 \\
3.3 \\
2.5 \\
6.9 \\
5.3\end{array}$ \\
\hline $\begin{array}{l}16 \\
17 \\
18 \\
19 \\
20\end{array}$ & $\begin{array}{l}42.4 \\
39.7 \\
37.6 \\
37.0 \\
33.9\end{array}$ & $\begin{array}{l}37.8 \\
37.5 \\
32.6 \\
32.3 \\
12.6\end{array}$ & $\begin{array}{c}4.4 \\
1.7 \\
2.0 \\
3.1 \\
15.3\end{array}$ & $\begin{array}{l}0.1 \\
0.5 \\
3.1 \\
1.6 \\
6.0\end{array}$ & $\begin{array}{c}13.6 \\
2.3 \\
3.8 \\
3.8 \\
18.3\end{array}$ \\
\hline $\begin{array}{l}21 \\
22 \\
23 \\
24 \\
25\end{array}$ & $\begin{array}{c}33.0 \\
29.3 \\
28.4 \\
20.3 \\
4.5\end{array}$ & $\begin{array}{c}29.9 \\
26.4 \\
7.9 \\
20.3 \\
1.9\end{array}$ & $\begin{array}{l}2.6 \\
1.7 \\
0.0 \\
0.0 \\
0.0\end{array}$ & $\begin{array}{c}0.6 \\
1.2 \\
20.5 \\
---- \\
2.6\end{array}$ & $\begin{array}{l}3.6 \\
5.9 \\
3.9 \\
1.4 \\
6.8\end{array}$ \\
\hline
\end{tabular}

